by a deep verandah on the south side. All windows and doors are steel-framed; the floors are for the most part parquet floors of Burmese teak. The verandah floors, however, and the floors of some of the laboratories are of salemite. The physics and chemistry laboratories deal with some four hundred students a week, the majority being pre-intermediate students. Post-graduate work is undertaken by very few students. The buildings of Judson College are similar in plan to those of University College but smaller.

The College buildings are separated by a short distance from their hostels. University College has eight men's hostels, each able to accommodate about one hundred and twenty students and managed by a warden, an assistant-warden, and tutors. Five of these hostels have a central dining-hall, while the other hostels have their own dining-halls. The hostel fees of men students, which include board and lodging, amount to about $f 2$ a month. In addition to these hostels for men, there is a hostel for women students, which accommodates about one hundred and twenty students and is managed on similar lines to the men's hostels. Judson College has two men's hostels and one women's hostel, all similar in construction to those of University College. All except three of the hostels are built of red brick and were designed by Mr. S. P. Bush, Government architect, Burma. The hostels of all the colleges can together accommodate about 1300 men students and about 300 women students. Both Colleges have large playing fields.

The University Convocation Hall is situated near the lake front at the north end of the estate, with the main buildings of University and Judson Colleges to east and west of it. It can hold some two thousand people and is one of the most striking buildings in Rangoon. It is a steel-framed brick building coated with cement plaster, and has a parquet flooring of Burmese padauk and is panelled with yinma, one of the most beautiful of the lighter-coloured Burmese hardwoods. The main doors are of bronze and open on to marble steps covered by a bronze marquise. The Convocation Hall, the main buildings of University and Judson Colleges, the University Library, and three of the University College hostels were designed by Mr. T. O. Foster.
The University Library was the gift of a generous donor who did much for the cause of education in Burma, Raja Dr. Reddiar, and has been built at a cost of some $£ 15,000$. The bookstack is to be fitted with an air-drying plant which will be, so far as is known, the first of its kind to be used in any library. The colleges already possess quite well-stocked general libraries, and the University Library is being devoted mainly to Oriental studies, including language, history, and art. In this connexion, University College has established a lectureship in Far Eastern history, and a considerable amount of work is being done in the University on the history of Burma.

'The University Students' Union building and the University gymnasium, both designed by $\mathrm{Mr}$. $\mathrm{T}$. $\mathrm{O}$. Foster, were the gifts respectively of Dr. Tun Nyo and $\mathrm{Mr}$. Chan Chor Khine. Both buildings are well equipped for the purposes for which they are used.

'The 'Teachers' 'Training College, designed by Mr. Armstrong, is situated in the southern part of the estate, and in addition to administrative and teaching buildings and hostels for men and women students, contains two practising schools, one for boys and one for girls, each with hostel accommodation for resident pupils. Provision has also been made for training in kindergarten work, and it is hoped that the College will supply what is the most urgent educational need in Burma, namely, well-trained teachers for the schools. The normal schools did excellent work in the face of great difficulties, but they lacked the resources now at the disposal of the Training College.

The engineering department of University College is housed in a set of buildings some half-mile distant from the main College buildings. For their erection a most munificent donation of $£ 100,000$ was made by the Burma Oil Company, and part of this donation has been used as an endowment towards the necessarily heavy expenses of upkeep.

Housing accommodation for the staffs of the constituent colleges and of the University has been provided by the Building Trust, which also has built a sanatorium for the students, a book-shop, a post office, a village for the servants of the colleges and the University, and quarters for the staff of the University training corps.

\title{
The Late Palæolithic Inhabitants of Palestine*
}

$\mathrm{T}$

HE skeletal material of late palæolithic age from Palestine, upon which Sir Arthur Keith reported to the International Congress of Prehistoric and Protohistoric Sciences at a meeting held on Aug. 3, was collected by Miss Dorothy Garrod from deposits in caves at Shukbah in the Judæan Hills in 1928, and on Mount Carmel in 1929, 1930, and 1931. For the industry with which the remains were associated, a new mesolithic industry, Miss Garrod proposes the name 'Natufian', after one of the sites on which it was found. An account of this industry was communicated to the Congress by Miss Garrod at a subsequent meeting held on Aug. 5.

Sir Arthur proposes that the people represented by these remains should also be known by the name of 'Natufian'; for, in his opinion, they were a peculiar people, not to be identified with any living race. They have affinities with the neolithic people of Malta, with the negroid element represented among European peoples in the Aurignacian period, and, more distantly, with the predynastic inhabitants of Egypt and the late palæolithic people of North Africa. Among living

* Substance of a paper read before the First International Congress of Prehistoric and Protohistoric Sciences, London, Aug, 1-6, by Sir Arthur Keith, F.R.S. peoples they approach most nearly to the Mediterranean race.

At Shukbah, remains of 45 individuals were found25 adults (9 males and 16 females), 17 children, and 3 adults of indeterminate sex. At Mount Carmel, on the terrace in front of the cave, was a veritable cemetery : 87 individuals were represented-35 adult males; 23 adult females, 23 children, and 6 indeterminate. The proportion of the remains representing a complete skull or skeleton is small. Only 20 individuals afford skull size and shape, and in many cases allowances have to be made for distortion due to pressure.

There are, however, several features which stand out definitely. They were a dolichocephalic people with a cephalic index varying from 72 to 78 ; they had cap-shaped occiputs ; the dimensions of the head are greater than in the predynastic Egyptians. They were prognathous, the sub-nasal prognathism being marked. The nasal bones formed a wide low arch ; and the chins were not prominent. Many had big heads.

The stature was low, few men exceeding $1.650 \mathrm{~m}$. ( $5 \mathrm{ft} .5 \mathrm{in}$.), most being about $\mathrm{I} \cdot 600 \mathrm{~m}$.; the women were about $1.524 \mathrm{~m}$. (5 ft.). A striking character is the strong development of the bones of thigh and leg 
in contrast to those of the arm, forearm, and shoulder. The thigh bones have a prominent linea aspera, the tibiæ are platycnemic. In more than half the humeri there is a perforation of the olecranon fossa.

Some interesting observations were made on the cultural practices of the Natufians, for which evidence was afforded by the skeletal remains. The two upper incisors of the women were extracted in youth. Evidence for the same practice was found by $\mathrm{Mr}$. Turville-Petre at Kebara, between Shukbah and Carmel. The Natufians also seem to have practised cannibalism. The bones are cut and fractured, the cut and broken surfaces showing that this was done when the bones were in a fresh state. This was at Shukbah only. No evidence of mutilation of the dead was found at Carmel or Kebara.
Evidence of a curious practice was found at Kebara. In the mesolithic deposits were found an assortment of bones which had been burned-not when fresh, but after they had been freed from animal matter by burial or exposure. The bones thus treated, which were collected by Mr. Turville-Petre, represent at least 75 individuals, mostly women. A similar collection had been forwarded to Sir Arthur by Mr. Leonard Woolley, which had been obtained from under the foundations of Ur. Here, too, women's bones preponderated. Further, Miss Caton-Thompson had obtained two skulls (female) from Zimbabwe which had been burned after the flesh had disappeared from the bones. Is this evidence, asks Sir Arthur, of a custom in ancient times of digging up the bones of ancestors and submitting them to the ordeal of fire?

\section{Recent Archæological Field Work in England}

$\mathrm{T}^{\mathrm{H}}$ OSE members of the International Congress of Prehistoric and Protohistoric Sciences who elected to join the excursions arranged for the week (Aug. 6-13) immediately following the meeting in London, were fortunate not only in being afforded an opportunity to visit a number of important sites, but also in having demonstrated to them the latest results of this season's work by those who are in charge where excavation is now proceeding.

After dividing into two parties, of which one made its headquarters at Cambridge and the other at Oxford, they rejoined at Salisbury. The Oxford party on the way to Salisbury visited Winchester and Easton Down, near Salisbury. At the latter, they were shown the flint mines discovered from the air by Dr. J. F. S. Stone two years ago, and since excavated by him. The site covers 100 acres, and has a system of $\mathrm{V}$-shaped ditches with deep pits at their convergence, similar to those of Grimes Graves, and containing quantities of half-manufactured implements, antler-picks and shoulder-blade shovels. Within the last few weeks, Dr. Stone has discovered a fresh pit of two courses, each eight feet in depth, with a shallower work nearby, which indicate how the neolithic miner worked.

Among the sites visited from Salisbury by the members of the Congress were the Iron Age fortress on Yarnbury Plateau and the Early Bronze Age site at Windmill Hill, which is being excavated by $\mathrm{Mr}$. Alexander Keiller. At Yarnbury the triple line of fortifications surrounds the largest prehistoric strong- hold in Wiltshire. It is $28 \frac{1}{2}$ acres in extent, with ramparts $25 \mathrm{ft}$. high. Within the triple rampart is a single rampart, or rather its remains, and a ditch. Some surprising results achieved in the excavations of the past two months were described by Mrs. M. E. Cunnington. The inner fortifications are not neolithic, as has been thought, but Iron Age work of a period slightly anterior to the triple line. The area was strewn with Romano-British pottery. A cutting in the interior rampart has revealed the post-holes for a chalk revetment sustained against a wooden wall. In the causeway, the only entrance to the fortress, has been found the most impressive Iron Age ditch so far discovered, a V-shaped excavation $12 \mathrm{ft}$. deep, so acute in angle that it would be impossible for two ranks of attackers to stand on the bottom. In the past few weeks there have also been discovered the guard-house and store-house of the fortress, while above the site of the ditch was the skeleton of a man wearing leather boots with hob-nails and bronze decorative studs.

At Windmill Hill, Mr. Keiller described the results of recent work, which now centres upon the excavation of the outer ditch, some $20 \mathrm{ft}$. wide and 8-9 ft. deep. Mr. Keiller announced that one-third of the site, which is the largest so far to be observed as included in this type of Early Bronze Age camp, is to be placed in trust for a century so that its excavation may be delayed until the results can be interpreted in the light of the fuller information which will then be available for archæologists.

\section{Submarine Gravity Survey in the Bahamas}

$\mathrm{A}^{\mathrm{N}}$ interesting piece of geophysical investigation has just been completed by an expedition carried out jointly by the United States Navy and the Department of Geology, Princeton University, with the co-operation of the United States Coast and Geodetic Survey. The introduction, in 1923, by Dr. Vening Meinesz of the Dutch Geodetic Commission, of a gravity pendulum apparatus capable of operating on a base not absolutely free from disturbing oscillation, led to the use of a submarine for the determination of the force of gravity over sea-beds and oceanbeds. During the next three years, three voyages in Dutch submarines were made by Dr. Vening Meinesz, and in the course of these he added much to the knowledge of the distribution of the force of gravity over the earth's surface.

In 1928 the United States showed an official appreciation of this pioneer work by inviting Dr. Vening
Meinesz to bring his apparatus and carry out a similar investigation in United States waters with the help of a submarine of the U.S. Navy. The cruise was carried out in the autumn of 1928 and covered an area of considerable geological interest in the Caribbean Sea, the Gulf of Mexico, and to the north of Porto Rico. With the land pendulum stations established in that region by the United States Coast and Geodetic Survey, a considerable body of evidence was thus made available for the study of questions of isostatic equilibrium and of tectonic development.

It was a natural consequence that a desire should be expressed by geophysicists for the extension of the investigation to cover the whole of the British West Indies. The consent of the British Government for a submarine of the United States Navy to operate in these waters was obtained, and Dr. Vening Meinesz once more placed his special pendulum apparatus and

No. 3277, VoL. 130] 